
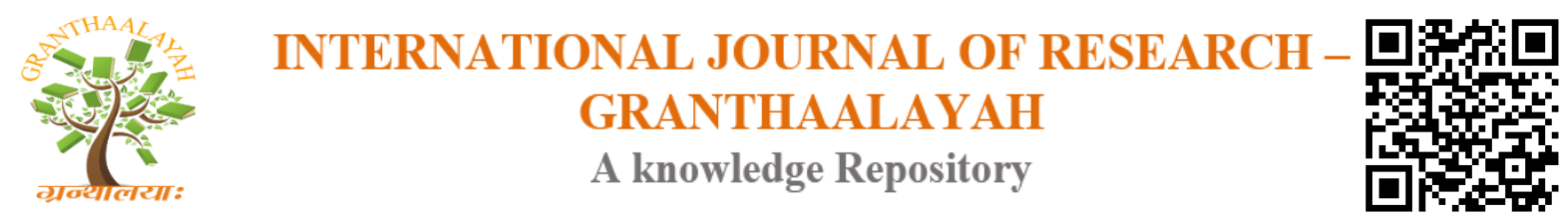

Management

\title{
AN EMPIRICAL STUDY ON IMPACT OF MICROFINANCE ON POVERTY ALLEVIATION IN RURAL INDIA
}

\author{
Shristy Poddar ${ }^{1}$, Sumit Bharti ${ }^{2}$, Kavitha S Sharma ${ }^{3}$ \\ ${ }^{1}$ M.Com \& CA Final, Univ. Dept. of Com. \& Busi. Admin., Bhagalpur, Bihar, India \\ ${ }^{2,3}$ Research Scholar, Univ. Dept. of Com. \& Busi. Admin., Bhagalpur, Bihar, India
}

\begin{abstract}
The dynamic development of the microfinance business has been advanced by market powers as well as by cognizant activities of national governments, Non-Governmental Organizations (NGOs), and the benefactors who view microfinance as a successful device for killing neediness. The incredible push behind this immense and expanding support for microfinance showed that national monetary and social effects are noteworthy and it should be analysed all the more intently.

Self Help Group (SHG) provides microfinance services for people in rural regions so they can use the capital for small business, productive work and become financially stable and independent. In this article, we have described the impact of microfinance on poverty alleviation its impacts on people and society. Here we have explained, the main purpose of this article is to present Microfinance and how it can be useful for poor people and the reduction of unemployment.
\end{abstract}

Keywords: Non-Governmental Organizations; Microfinance; Self Help Group; Society; Poverty; Unemployment.

Cite This Article: Shristy Poddar, Sumit Bharti, and Kavitha S Sharma. (2019). "AN EMPIRICAL STUDY ON IMPACT OF MICROFINANCE ON POVERTY ALLEVIATION IN RURAL INDIA." International Journal of Research - Granthaalayah, 7(7), 304-309. https://doi.org/10.29121/granthaalayah.v7.i7.2019.768.

\section{Introduction}

India has the one of the quick creating nation on the planet. India's 'first world' economy is situated to the most noteworthy models of globalize utilization, and formal area wages and ways of life mirror this. On the other hand, the genuine earnings and 'ways of life' of the exceptionally poor, especially in provincial zones, are practically identical low. Smaller scale account is frequently pushed as an answer for different social issues in India. Poor Persons with access to credit can make interests in ventures that bring them out of destitution. In the course of the most recent couple of years, investment funds and credit gatherings have likewise dealt with some significant social projects of the Indian government, for example, the appropriation of nourishment grains and school dinners in state elementary schools. Salary in India is firmly connected to social and financial 
status: while the upper and working classes occupy the 'formal' pay from their formal endeavors and business, in other hand the least fortunate and low pay status are to a great extent 'casually' utilized. Low salary families are not typically engaged with ordinary pay, occupation and in this way sitting tight for employment creation systems to assimilate them; they 'for all time occupy' a needy portion of the supposed creating Indian economy, in which open doors for employments, or for autonomous and self-continuing pioneering capital amassing, are negligible. In spite of the fact that neediness decrease has for some time been a high need for the Government of India, microfinance is a still test apparatus in its general procedures. India's microfinance trials are much contrast from the more generous microfinance organizations and projects of its neighbours nations. The United Nations framework was maybe the primary worldwide accomplice to India's new tests with little scale credit plans. The vast majority of needy individuals figure out how to improve assets over an opportunity to build up their ventures. Budgetary administrations could empower the poor to use their drive, quickening the way toward producing wages, resources and monetary security. Notwithstanding, regular account establishments only sometimes loan down-market to serve the requirements of low-salary families and ladies headed families. They are all the time denied access to credit for any reason, making the exchange of the degree of loan cost and different terms of money superfluous. In this way the central issue isn't such a large amount of excessively expensive terms of advance as the absence of access to credit itself. The effect of microfinance on neediness decrease has been estimated as far as a few measurements, for example, improved salary, work and family unit consumption, and diminished powerlessness to financial and social emergencies.

\subsection{Poverty: Concept and Measures}

Destitution and joblessness issues have been the topic of exchange for some created nations. Regularly neediness is portrayed as the foe of humankind and it is believed to be the gross infringement of our development. The History of humanity exhibits that destitution is only a revile, not just for the person who is poor, but for rest of the network, country and worldwide society on the loose. It forces individuals to imagine that starvation, hopelessness and hardship are normal revile of life, and the needy individuals are not entitles for living a superior lives.

In the fundamental work on neediness and starvations, Nobel laureate educator Amartya Sen assessed the causation of starvation and starvations and proposed the privilege approach as an elective strategy for getting destitution.

\section{Review of Literature}

Panigrahi shobhi (2008) characterized microfinance as a framework that gives little credits to poor business visionaries in explicit scale independently employed bungalow and locally established organizations which become the most current silver slug for mitigating neediness. The huge development of microfinance happens in India, because of the escape clauses in India, because of the provisos in Indian financial industry. They pointed that the capability of microfinance is more in India when contrasted with other piece of world because of accessibility of 7.5 crore poor and their interest for little credits. Further they expressed various wellsprings of subsidizing to MFIs in India. The nearness of keys issues in country financing like absence of credit, low sparing limit and predominance of usurious cash loan specialists gives degree to 
microfinance advancement. They propose practical working of both MFIs and country bank offices to cover the hole of credit availability and make microfinance effective.

Shrestha (2010) investigated the Microfinance and social activation with regards to ADBL (Agricultural Development Bank, Nepal) in advancing SFCLs (Small Farmers Cooperative Limited) in his book entitled "Money related Performance of Small Farmers Co-employable Limited in Nepal." She found that social preparation is likewise similarly required so as to improve and keep up the better monetary exhibitions of SFCLs.

Ramanathan (2008): characterized SHGs as the little, monetarily homogeneous liking gathering of 10 to 20 poor people meeting up to spare limited quantity routinely by commonly consenting to add to a typical store in gathering their crisis needs with aggregate basic leadership to determine clashes through shared choice to get insurance free advances on terms chosen by gathering at market driven rates. NABARD goes about as significant player as propagator and facilitator by giving conductive arrangement condition, preparing, limit constructing and expanding money related help for the development of SHGs linkage program. With the test case program in 1992 by connecting 500 SHGs, the NABARD has made an extraordinary history by connecting 29, 24,973 SHGs in 2006-2007.

Puhazhendi and Badatya (2002) completed an investigation to evaluate the effect of microfinance channelized through SHG Bank Linkage program executed by NABARD since 1992 in Eastern zones (Orissa, Jharkhand and Chhattisgarh) of the nation in 2001-02. The examination depended on essential subtleties gathered from 115 individuals in 60 SHGs. The financial states of the individuals were thought about among pre and post SHG circumstances to evaluate the effect. The discoveries of the investigation inferred that SHG Bank Linkage Program has made huge commitment to social and financial improvement of the part families of SHGs.

Ramanathan (2008) defined SHGs as the small, economically homogeneous affinity group of 10 to 20 poor persons coming together to save small amount regularly by mutually agreeing to contribute to a common fund in meeting their emergency needs with collective decision making to resolve conflicts through mutual decision making to resolve conflict through mutual decision to get collateral free loans on terms decided by group at market driven rates. NABARD acts as major player as propagator and facilitator by providing conductive policy environment, training, capacity building and extending financial support for the growth of SHGs linkage program. With the pilot program in 1992 by linking 500 SHGs, the NABARD has created an unforgettable history by linking 29, 24,973 SHGs in 2006-2007.

Karmakar (2002), stated that SHGs as an approach towards alleviation of poverty. According to him poor people hold tentative and uncertain behaviour while, the group membership helps in removing this rough edge behaviour pattern. SHGs work on the principle of cooperation and mutual help which tries to fulfil the individual member's financial and social requirements.

Majumdar (2009) highlighted evolution, growth and impact of micro credit in India. He defined micro credit as specific loans to the poor and credit needs of clients, while Microfinance as broader range of financial services which create wider range of opportunities to the poorest spectrum of society. In spite of great economic revolution and rapid strides in the knowledge sector, India 
remains home of largest population of poor's in the world. He differentiates between burden of micro credit and credit through informal sources. He stated different models through which SHGs are controlled and supervised, and share of different banks participation in Microfinance activities till 2004.

In a study, Khandker (1998) found that $10 \%$ increase in borrowing from a microfinance institution reduces the probability of being below the poverty line by $0.3 \%$ for males and by $0.2 \%$ for females. Another study conducted by Khandker (2003) also revealed that, microfinance helps to reduce extreme poverty $(18 \%)$ much more than moderate poverty $(8.5 \%)$.

\section{Rural India and Microfinance}

Micro financing has turned out to be significant since the likelihood of a sub-Rs 1,000 portable handset has been precluded sooner rather than later. Provincial India can by and large bear the cost of handsets in the value scope of Rs. 1,500-2,000. To prevail in India, agribusiness must engage the rancher by making horticulture gainful, not by dispossessing him adversary this specific reason the rancher ought to be supported for their essential and little needs. Small scale fund is relied upon to assume a huge job in neediness mitigation and improvement. The need, consequently, is to share encounters and materials which will help in getting victories and disappointments as well as give information and rules to reinforce and grow miniaturized scale account programs. The improvement procedure through a common miniaturized scale fund mediation can be comprehended with the assistance of the accompanying Chart a definitive point is to accomplish social and financial strengthening. Fruitful intercession is in this way, subject to how every one of these stages has been painstakingly managed and furthermore the abilities of the executing associations in accomplishing the last objective, e.g., if credit conveyance happens without union of SHGs, it might have issues of self-maintainability and recuperation. Various plans under banks, focal and state governments offer direct credit to potential people without compelling them to join SHGs. Arrangement and characterization of the correspondence materials in the catalogue is done dependent on this improvement procedure.

\subsection{Profile of Rural India}

- 350 million Below Poverty Line

- $95 \%$ have no entrance to microfinance.

- $56 \%$ individuals still get from casual sources.

- $70 \%$ don't have any store account.

- $87 \%$ no entrance to credit from formal sources.

- Annual credit request is about Rs.70, 000 crores.

- $95 \%$ of the families are with no sort of protection.

- Informally Microfinance has been by and by for a very long time.

\section{Objective of the Study}

The objectives of the study are as follows

- To analyze the growth of microfinance sector developed in India

- To analyze the pattern of microfinance programme in rural Indian. 
- To study the role of microfinance in poverty alleviation

- To study the scheme various scheme run by Govt. of India

\section{Research Methodology}

This is an elucidating exploration paper dependent on optional information. Information have been discovered by googling in various sites, research paper and magazines.

\section{Few Scheme of a Government of India}

There are such a significant number of plans for the up-liftment of poor In India. One of them Micro-credit projects is run essentially by NABARD in the field of agribusiness and SIDBI in the field of Industry, Service and Business (ISB). The accomplishment of Micro-credit program lies in expansion of administrations. Smaller scale Finance Scheme of SIDBI is under task since January, 1999 with a corpus of Rs. 100 crore and a system of around 190 limit surveyed evaluated MFIs/NGOs. Under the program, aggregate sum of Rs. 191 crore have been endorsed upto 31st December, 2003, profiting more than 9 lakh recipients. Under the program, NGOs/MFIs should give value support so as to benefit SIDBI money. Be that as it may, they think that its hard to deal with the required value support due to their poor money related condition. The issue has disturbed due to declining financing cost on stores. The workplace of the improvement magistrate (Small Scale Industries) under Ministry of SSI is propelling another plan of Micro Finance Program to conquer the limitations in the current plan of SIDBI, whose compass is as of now low. It is felt that Government's job can be basic in extending reach of the plan, guaranteeing long haul supportability of NGOs/MFIs and improvement of Intermediaries for recognizable proof of practical activities.

\section{Salient Features of Micro-Finance Programme of Government of India}

Organizing fixed stores for MFIs/NGOs: Under this plan administration of India mastermind cash to MFI/NGO like SIDBI for smaller scale credit to poor. Preparing and concentrates on smaller scale account program: Government of India would help SIDBI in gathering the preparation needs of NGOs, SHGs, go-betweens and business visionaries and furthermore in improving mindfulness about the program. Establishment working for 'delegates' for recognizable proof of feasible ventures: The Government of India would help in foundation working through distinguishing proof and advancement of 'mediator association', which would support the NGOs/SHGs in ID of item, readiness of task report, working out forward and in reverse linkages and in fixing showcasing/innovation tie-ups. The SISIs would help in the distinguishing proof of such middle people in various zones. Budgetary arrangement for the plan during tenth arrangement: There was a budgetary arrangement in tenth multi year plan and trusting more assets in next arrangement. Managerial game plan: An advisory group has been shaped to control and screen the regulatory game plan of MFI/NGOs.

\section{Findings}

Considerable hole among interest and supply for every single money related administration. 
Majority of poor are avoided from money related administrations. This is expected to, interalia, the accompanying reasons:

Bankers feel that it is hazardous to fund poor people groups due to their financial soundness. High exchange costs

\section{Conclusion}

We can infer that microfinance assumes a huge job in monetary improvement process. Microfinance add to financial and social advancement through work age However, while recognizing the essential job of microfinance there is differing discernment over the fore notice jobs from different improvement partners. It is excellent wellspring of store in battling against neediness however without sportive ability advancement, it is exceptionally hard to discover it. The present condition of the poor people could have been exceptionally poor without the assistance from microfinance mediations. Along these lines, microfinance is by all accounts of all-around conveniently connect in a lifting needy individuals out of extraordinary neediness.

\section{References}

[1] Bashyal, R. (2005). Impact of microcredit programs on poverty alleviation in Nepal: A case study of Rupandehi district. (A Ph.D. dissertation submitted to Tribhuvan University), Kathmandu

[2] Chen, M.A. and Snodgrass, D. (1999), "An Assessment of the impact of SEWA Bank in IndiaBase line findings", AIMS, USAID, Washington D.C.

[3] Cohen, M. and Chen,M.A. (1997), "A Guide for assessing the microenterprise services at the individual level"' AIMS, USAID, Washington, D.C.

[4] Panda, D.K. (2009), "Understanding Microfinance", Wiley India, New Delhi.

[5] Puhazhendi, V. and Badatya, K.C. (2002), "SHG -Bank Linkage Programme for Rural Poor-An Impact Assessment", NABARD.

[6] Puhazhendhi,V. \& Satyasai, K.J.S.(2002)“ Empowerment of Rural Women through Self Help Groups-An Indian Experience”, National Bank News Review, (June 2002).

[7] Report of ministry of small scale industries India published on website www.ssi.ac.in

[8] Yunus, Muhammad (2003). Banker to the Poor: Micro-lending and the Battle Against World Poverty. Public Affairs, New York.

[9] Mahmud, Wahiduddin. (2008). "Bangladesh". In Anis Chowdhury and Wahiduddin Mahmud (eds) (2008). Handbook on South Asian Economies. Edward Elgar, Cheltenham.

[10] World Bank (2008). World Development Report, 2008. The World Bank, Washington DC.

[11] Ahmed, Shamim, and Ezazul Islam (2006). "Interest Rate Responsiveness of Investment Spending in Bangladesh: A VAR Approach". Bangladesh Bank Working Paper 0608.

\footnotetext{
*Corresponding author.
}

E-mail address: kamran.tmbu@gmail.com/ sbharatica2007@gmail.com/ kavithasharma01@yahoo.com 